\title{
Energy values and standardized ileal digestibility of amino acids in some feedstuffs for broilers
}

\section{Valores energéticos e digestibilidade ileal estandardizada de aminoácidos de alguns alimentos para frangos de corte}

\author{
Felipe Santos Dalólio ${ }^{1 *}$; Diego Ladeira da Silva ${ }^{1}$; Luiz Fernando Teixeira Albino; \\ Ricardo Vianna Nunes ${ }^{3}$; Valdir Ribeiro Júnior ${ }^{4}$; Horácio Santiago Rostagno²; \\ Helvio da Cruz Ferreira Junior ${ }^{1}$; Sandra Regina Freitas Pinheiro ${ }^{5}$
}

\begin{abstract}
The objective of this study was to determine the energy values, standardized ileal digestibility coefficients and digestible amino acid contents of parboiled brown rice bran (PBRB), protein sorghum meal (PSM) and bread waste meal (BWM) in broiler diets. In the first trial, 144 broiler chicks at 14 days of age were evaluated in a completely randomized design involving three feedstuffs + a control diet, with six replicates and six birds per experimental unit. The total excreta collection method was adopted to determine the energy values of the feedstuffs. In the second trial, 144 broilers at 24 days of age were used in a completely randomized design involving three feedstuffs + a protein-free diet, with six replicates and six birds per experimental unit. Ileal digesta was harvested to determine the standardized ileal digestibility coefficients and digestible amino acid contents of the feedstuffs. The nitrogen-corrected apparent metabolizable energy (AMEn) values of PBRB, PSM and BWM were 2638, 2799 and $3399 \mathrm{kcal} . \mathrm{kg}^{-1}$, respectively. The metabolizability coefficients of AMEn (CAMEn) of PBRB, PSM and BWM were 54.13, 57.35 and $86.66 \%$, respectively. Bread waste meal had the highest CAMEn $(\mathrm{p}<0.05)$ and standardized ileal digestibility of amino acids $(\mathrm{p}<0.01)$, followed by PBRB and PSM. The main limiting digestible amino acids in PBRB, PSM and BWM were found at the following respective levels: methionine $-0.19,0.33$ and $0.24 \%$; lysine $-0.40,0.46$ and $0.40 \%$; threonine -0.25 , 0.50 and $0.45 \%$; and valine $-0.44,0.73$ and $0.48 \%$.
\end{abstract}

Key words: Alternative feedstuffs. Coefficients. Poultry farming. Metabolizability.

\section{Resumo}

Objetivou-se determinar os valores energéticos, os coeficientes de digestibilidade ileal estandardizada e os teores de aminoácidos digestíveis do farelo de arroz integral parboilizado (FAIP), do farelo proteico de sorgo (FPS) e do farelo de resíduo de pão (FRP) em dietas para frangos de corte. No primeiro experimento, foram utilizados 144 pintos de corte com 14 dias de idade, distribuídos em delineamento inteiramente casualizado, com três alimentos + uma dieta referência, com 6 repetições e 6 frangos

1 Pesquisadores, Universidade Federal de Viçosa, UFV, Viçosa, MG, Brasil. E-mail: felipesantos181@hotmail.com; diegoladeira@ hotmail.com; helvio_cruz@hotmail.com

2 Prof., UFV, Viçosa, MG, Brasil. E-mail: lalbino@ufv.br; rostagno@ufv.br

3 Prof., Universidade Estadual do Oeste do Paraná, UNIOESTE, Marechal Cândido Rondon, PR, Brasil. E-mail: nunesrv@ hotmail.com

4 Prof., Universidade Federal de Sergipe, UFS, São Cristóvão, SE, Brasil. E-mail: vrj_zoo@hotmail.com

5 Prof $^{\mathrm{a}}$,UniversidadeFederal dos Vales do Jequitinhonhae Mucuri,UFVJM, Diamantina, MG, Brasil.E-mail: sandrafreitaspinheiro@ gmail.com

* Author for correspondence 
por unidade experimental. Foi utilizado o método de coleta total de excretas para determinar os valores energéticos dos alimentos. No segundo experimento, foram utilizados 144 frangos de corte com 24 dias de idade, distribuídos em delineamento inteiramente casualizado, com três alimentos + uma dieta isenta de proteína, com 6 repetições e 6 frangos por unidade experimental. A coleta da digesta ileal foi utilizada para determinar os coeficientes de digestibilidade ileal estandardizada e o teor de aminoácidos digestíveis dos alimentos. Os valores de energia metabolizável aparente corrigida pelo balanço de nitrogênio (EMAn) do FAIP, do FPS e do FRP foram 2638, 2799 e $3399 \mathrm{kcal}^{\mathrm{kg}}{ }^{-1}$, respectivamente. Os coeficientes de metabolizabilidade da EMAn (CEMAn) do FAIP, do FPS e do FRP foram 54,13, 57,35 e 86,66\%, respectivamente. Os CEMAn $(\mathrm{p}<0,05)$ e da digestibilidade ileal estandardizada dos aminoácidos $(\mathrm{p}<0,01)$ do FRP foram maiores, seguido pelo FAIP e FPS. Os valores dos principais aminoácidos limitantes digestíveis do FAIP, do FPS e do FRP foram 0,19, 0,33 e 0,24 para a metionina; $0,40,0,46$ e 0,40 para lisina; $0,25,0,50$ e 0,45 para treonina; e $0,44,0,73$ e 0,48 para valina, respectivamente.

Palavras-chave: Alimentos alternativos. Coeficientes. Avicultura. Metabolizabilidade.

\section{Introduction}

The costs incurred in broiler feeding can represent up to $75 \%$ of the total chicken meat production costs. This impact is further evident when corn and soybean meal are used as the main diet ingredients. However, when the use of alternative feedstuffs in diet formulations is examined, the cost factor becomes one of the variables in the process that can improve the gain margin for big companies. For this, the metabolizable energy and digestible amino acid values of feedstuffs should be determined so that formulations can be optimized (DALÓLIO et al., 2017). In this scenario, considering the formulation of broiler diets based on the 'ideal protein' concept and digestible amino acid values, the producer must know the standardized ileal digestibility of amino acids in feedstuffs. The dependence of the poultry sector on soybean meal and corn generates a demand for unconventional, low-cost regional feed sources, which, according to the desired objective, may greatly elevate marginal production gains.

Some researchers (FREITAS et al., 2013; QUEVEDO-FILHO et al., 2013; ZARE-SHEIBANI et al., 2015) observed that brown rice bran can be an excellent alternative to be included in the diet of Japanese quail during the starter and laying phases; and for broilers, when aiming to cheapen their feed, replacing corn. Rostagno et al. (2017) asserted that rice bran has a standardized ileal digestibility coefficient of amino acids of $70 \%$, on average, and $13.30 \% \mathrm{CP}$. However, parboiled brown rice bran (PBRB) has not yet been evaluated in terms of digestible amino acid contents for broilers, warranting the need for studies involving this ingredient in the formulation of diets based on the 'ideal protein' concept.

Barekatain et al. (2013) stated that sorghum distillers' dry grains with solubles (DDGS) is a potential ingredient for poultry farming due to its high $\mathrm{CP}$ content, satisfactory metabolizable energy values and low cost compared to other protein sources such as soybean meal. Sorghum DDGS is the main substrate of protein sorghum meal (PSM). Furthermore, PSM contains residues from germ and gluten production and from the extraction of sorghum oil. To the present date, there are no reports of the use of PSM in broiler diets regarding energy metabolizability, standardized ileal digestibility of the protein fraction and digestible amino acid content. Thus, determining the metabolizable energy values and the digestible amino acids in PSM will enable its use in broiler diets.

Bakery wastes may constitute high-energy alternatives of great relevance, with considerable amino acid digestibility (STEFANELLO et al., 2016). According to Rostagno et al. (2017) bread waste meal (BWM) has an average standardized ileal digestibility coefficient of amino acids of $90.0 \%$ and $12.10 \%$ CP. However, bakery wastes such as breads and biscuits vary widely in their 
composition due to variations in the ingredients and additives used in their manufacture and variations in wheat (NUNES et al., 2001; BROCH et al., 2015). Because of this variability, the energy values and digestible amino acid contents of wheat by-products should be constantly updated. Additionally, industrial additives should be included as they are able to influence nutrient utilization by birds, as is the case of BWM.

On these bases, the present study proposes to determine the apparent metabolizable energy (AME), nitrogen-corrected AME (AMEn), metabolizability coefficients (CAME and CAMEn), standardized ileal digestibility coefficient and digestible amino acid values of PBRB, PSM and BWM in broiler diets.

\section{Material and Methods}

Two digestibility trials were carried out to evaluate the metabolizable energy and digestible amino acid contents of three alternative feedstuffs. All procedures involving research animals were approved by the Ethics Committee on Production Animals at the Federal University of Viçosa (approval no. 043/2015).

The first trial involved 144 chicks of the Cobb 500 strain at 14 days of age, with an average weight of $445.0 \pm 5.0 \mathrm{~g}$. Birds were reared from birth until 13 days of age in a masonry shed with wood shavings litter where they received a mash diet based on corn and soybean meal for the starter period, following the recommendations of Rostagno et al. (2011), containing $2950 \mathrm{kcal} \mathrm{kg}^{-1} \mathrm{ME}$ and $21 \%$ CP. At 14 days, the birds were transferred to metal cages equipped with trough feeders, nipple drinkers and a plastic-lined tray for excreta collection. The experiment was set up as a completely randomized design with four treatments (three feedstuffs: parboiled brown rice bran [PBRB; 40\% inclusion], protein sorghum meal [PSM; 30\% inclusion], bread waste meal [BWM; 70\% inclusion] + a basal/ diet [control]), six replicates and six birds per experimental unit. Control diet was formulated based on corn and soybean meal, following the recommendations proposed by Rostagno et al. (2011) for the period of 14 to 24 days of age (Table $1)$.

The experimental period was ten days, consisting of five days of adaptation followed by five days of total excreta collection. Total excreta were collected daily, starting on the sixth experimental day. Samples were subsequently frozen at $-20{ }^{\circ} \mathrm{C}$ to prevent bacterial fermentation. Next, the collected excreta were weighed, homogenized, sampled and pre-dried at $55{ }^{\circ} \mathrm{C}$ in a forced-air oven at $72 \mathrm{~h}$ to determine the dry matter (DM), gross energy (GE) and nitrogen $(\mathrm{N})$ contents (SILVA; QUEIROZ, 2002). Apparent metabolizable energy (AME), nitrogen-corrected AME (AMEn) and respective metabolizability coefficients (CAME and CAMEn) were calculated based on the results of $\mathrm{N}$ and GE, using the equations proposed by Sakomura and Rostagno (2016).

In the second trial, 144 male Cobb-500 broilers at 24 days of age, with an average initial weight of $885.00 \pm 10.0 \mathrm{~g}$, were used in a completely randomized design with four treatments (the same feedstuffs used in the first trial plus a starchbased, protein-free basal diet [control]) (Table 1), six replicates and six birds per experimental unit. Acid insoluble ash (Celite ${ }^{\mathrm{TM}}$ ) was added to all diets in the amount of $1 \%$. Birds received the basal diet following the recommendations proposed by Rostagno et al. (2011), containing $2980 \mathrm{kcal} \mathrm{kg}^{-1}$ ME and $20 \%$ CP, until the 23 rd day of life. The broiler chickens were subsequently housed from the 24th to the 28th days of age in cages where they received the experimental diets. After an adaptation period of four days, they were slaughtered by electronarcosis for ileal digesta collection. For this step, the abdominal cavity was sectioned and all intestinal content present at $40 \mathrm{~cm}$ from the portion of the terminal ileum, anterior to the ileocecal junction, was removed. Ileal digesta samples were vacuum freeze-dried at a temperature of $-40{ }^{\circ} \mathrm{C}$ for 
$72 \mathrm{~h}$ and then laboratory analyses were performed to determine the total amino acid contents by highperformance liquid chromatography (HPLC), following the methodology described by AOAC (1995). The DM and N contents in the digesta were also determined (SILVA; QUEIROZ, 2002). Acid insoluble ash and the indigestibility factor were measured in accordance with Joslyn (1970). The standardized ileal digestibility coefficients of amino acids were calculated by the methodology proposed by Sakomura and Rostagno (2016).

Table 1. Composition of experimental diets used for the determination of metabolizable energy values and content of digestible amino acids of feedstuffs.

\begin{tabular}{|c|c|c|c|}
\hline Diet reference basal $^{1}$ & & Protein free basal diet ${ }^{2}$ & \\
\hline Ingredients & & Ingredients & \\
\hline Corn & 72.886 & Starch & 80.310 \\
\hline Soybean meal & 2.368 & Sugar & 5.000 \\
\hline Soy oil & 1.000 & Soy oil & 5.000 \\
\hline Dicalcium phosphate & 1.609 & Dicalcium phosphate & 2.100 \\
\hline Limestone & 0.926 & Limestone & 0.700 \\
\hline Comum salt & 0.481 & Comum salt & 0.450 \\
\hline DL-methionine (99\%) & 0.146 & Potassium carbonate & 1.000 \\
\hline L-lysine $\mathrm{HCl}(78 \%)$ & 0.168 & Corn cob & 4.000 \\
\hline L-threonine (98\%) & 0.001 & Vitamin supplement $^{3}$ & 0.150 \\
\hline Vitamin supplement ${ }^{3}$ & 0.100 & Mineral supplment $t^{4}$ & 0.080 \\
\hline Mineral supplement ${ }^{4}$ & 0.100 & Choline chloride $(60 \%)$ & 0.200 \\
\hline Choline chloride $(60 \%)$ & 0.100 & $\mathrm{BHT}^{6}$ & 0.010 \\
\hline Salinomycin $(12 \%)^{5}$ & 0.055 & Acid insoluble ash $\left(\right.$ Celite $\left.^{\mathrm{TM}}\right)$ & 1.000 \\
\hline BHT $^{6}$ & 0.010 & & \\
\hline Total & 100.000 & Total & 100.000 \\
\hline \multicolumn{4}{|l|}{ Calculated composition } \\
\hline Metabolizable energy (kcal/kg) & 3050 & - & - \\
\hline Crude protein $(\%)$ & 16.14 & - & - \\
\hline Digestible lysine (\%) & 0.847 & - & - \\
\hline Digestible methionine (\%) & 0.395 & - & - \\
\hline Digestible methionine + cystine $(\%)$ & 0.610 & - & - \\
\hline Digestible threonine $(\%)$ & 0.550 & - & - \\
\hline Digestible tryptophan (\%) & 0.166 & - & - \\
\hline Calcium (\%) & 0.819 & - & - \\
\hline Non-phytate phosphorus (\%) & 0.391 & - & - \\
\hline Sodium $(\%)$ & 0.210 & - & - \\
\hline
\end{tabular}

${ }^{1}$ Diet reference used to evaluate the metabolizable energy values of feedstuffs. ${ }^{2}$ Diet reference used to evaluate the standardized amino acids coefficients and content of digestible amino acids. ${ }^{3}$ Composition for kg of product: manganese, $75,000 \mathrm{mg}$; iron, 20000 mg; zinc, 50,000mg; copper, 4,000mg; cobalt, $200 \mathrm{mg}$; iodine 1,500mg and qsp, 1.000g. ${ }^{4}$ Composition for kg of product: vit. A, 12000000 UI; vit. D3, 2200000 UI; vit. E 30000 UI; vit. B1, 2200 mg; vit B2, 6000 mg; vit. B6, 3300 mg; pantothenic acid, $13000 \mathrm{mg}$; biotin, $110 \mathrm{mg}$; vit. K3, $2500 \mathrm{mg}$; folic acid, $1000 \mathrm{mg}$; nicotinic acid $530000 \mathrm{mg}$; niacin, $25000 \mathrm{mg}$; vit. B12, $16000 \mu \mathrm{g}$; selenium, 0,25g; antioxidant $120000 \mathrm{mg}$, and qsp, 1000 g. ${ }^{5}$ Anticoccidial. ${ }^{6}$ Butyl Hydroxy Toluene. 
The experimental data were subjected to analysis of variance (ANOVA) at the 5\% probability level and means were compared by Tukey's test at the 5\% probability level. All analyses were performed using the System for Statistical and Genetic AnalysisUFV (SAEG, 2007).

\section{Results and Discussion}

Differences were detected between the feedstuffs for AMEn and CAMEn, the highest values of which were observed for BWM $(\mathrm{p}<0.05)$ (Table 2).

The variable composition of the many wheat byproducts and across different types of ingredients used in the manufacture of different types of breads and biscuits are factors contributing to the variability observed in metabolizable energy utilization by broilers (NUNES et al., 2001). The AMEn and CAMEn values of BWM found in the present study were close to the $3352 \mathrm{kcal} \mathrm{kg}^{-1}$ and $85.37 \%$ observed by Rostagno et al. (2011). However, they were lower than the $3494 \mathrm{kcal}^{\mathrm{kg}} \mathrm{kg}^{-1}$ and $89 \%$ reported by Silva et al. (2012). Nunes et al. (2001), in turn,

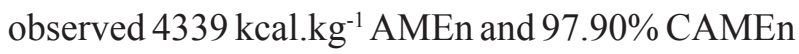
in biscuit waste used in broiler diets. Broch et al. (2015) investigated the metabolizability of energy from wheat and its derivatives and found variations of 42 to $73 \%$ for CAMEn, due to differences in the composition and utilization of the feedstuffs.

Table 2. Means values of dry matter (DM), crude protein (CP), gross energy (GE), apparent metabolizable energy (AME), nitrogen-corrected apparent metabolizable energy (AMEn), metabolizability coefficients of AME and AMEn of feedstuffs.

\begin{tabular}{lccccc}
\hline Feedstuffs & PBRB & PSM & BWM & CV (\%) & p - value \\
\hline $\mathrm{DM}(\%)$ & 88.21 & 89.13 & 88.01 & - & - \\
$\mathrm{CP}(\%)$ & 13.71 & 42.65 & 15.26 & - & - \\
$\mathrm{GE}\left(\mathrm{kcal} . \mathrm{kg}^{-1}\right)$ & 4873 & 4880 & 3922 & - & - \\
$\mathrm{AME}^{1}\left(\mathrm{kcal}_{\mathrm{kg}}\right)$ & $2653 \pm 266^{\mathrm{b}}$ & $2819 \pm 72^{\mathrm{b}}$ & $3541 \pm 97^{\mathrm{a}}$ & 5.62 & $<0.001$ \\
$\mathrm{AMEn}^{1}\left(\mathrm{kcal} / \mathrm{kg}^{-1}\right)$ & $2638 \pm 266^{\mathrm{b}}$ & $2799 \pm 72^{\mathrm{b}}$ & $3399 \pm 92^{\mathrm{a}}$ & 5.70 & $<0.001$ \\
$\mathrm{CAME}^{2}(\%)$ & $54.44 \pm 5.46^{\mathrm{b}}$ & $57.76 \pm 1.49^{\mathrm{b}}$ & $90.27 \pm 2.48^{\mathrm{a}}$ & 5.28 & $<0.001$ \\
$\mathrm{CAMEn}^{2}(\%)$ & $54.13 \pm 5.46^{\mathrm{b}}$ & $57.35 \pm 1.47^{\mathrm{b}}$ & $86.66 \pm 2.34^{\mathrm{a}}$ & 5.35 & $<0.001$ \\
\hline
\end{tabular}

${ }^{\mathrm{a}-\mathrm{b}}$ Different letters in the same line differ by Tukey test $(\mathrm{p}<0.05) .{ }^{1}$ Expressed as natural matter. ${ }^{2}$ Expressed as dry matter. $\mathbf{P B R B}=$ Parboiled brown rice bran; PSM = Protein sorghum meal; BWM = Bread waste meal; CV $(\%)=$ Coefficient of variation .

Rostagno et al. (2017) mentioned that the practical BWM inclusion level recommended for broiler diets is 10 and $15 \%$ for the starter and grower phases, respectively. Ayanrinde et al. (2014), on the other hand, claimed $33 \%$ bakery waste meal can be used to replace corn without losses to the performance or carcass yield of broilers. However, Oke (2013) stated that, despite reducing production costs, replacing corn with $30 \%$ BWM compromises performance and carcass yield, in broilers. Thus, these divergences suggest a need for further research on the use of BWM in broiler diets.
Brown rice has some antinutritional factors that limit its use in poultry diets, such as the possibility of hydrolytic and oxidative rancidification of fat during storage, presence of phytate, high fiber contents and trypsin and hemagglutinin inhibitors (GALLINGER et al., 2004; LACERDA et al., 2013). Though approximately $20 \%$ of rice bran is starch, the largest carbohydrate portion in this feedstuff are indigestible fiber fractions, e.g. hemicellulose and cellulose, which are found at high values in brown rice (SHAHEEN et al., 2015). According to Dias et al. (1994), the cellulose, hemicellulose 
and lignin contents in rice are 2.64, 17.30 and $20.90 \%$, respectively. In the parboiling process, brown rice undergoes thermal processing by precooking, autoclaving and drying before the steps of husking, grinding and polishing. Denardin and Silva (2009) stated that this may be the explanation for the variations in ether extract and available starch contents in it. Together, the above-mentioned factors explain the $2639 \mathrm{kcal} \mathrm{kg}^{-1}$ AMEn and the low CAMEn of $54.13 \%$ in PBRB observed in the current study, indicating low utilization of the gross energy in this feedstuff.

The AMEn and CAMEn values of PBRB found in the present study differ from the $2446 \mathrm{kcal} . \mathrm{kg}^{-1}$ and $61.04 \%$ observed by Generoso et al. (2008). By comparing the present data to those observed by Generoso et al. (2008), we observe that the parboiling process increased AMEn by $7.85 \%$ and reduced CAMEn by $11.32 \%$. The increase in AMEn resulted from the parboiling process deactivating the lipase enzymes that cause rancidity in brown rice during storage (LACERDA et al., 2013) and the fact that the pre-cooking temperature (around $60{ }^{\circ} \mathrm{C}$ ) of brown rice causes partial gelatinization of starch. The reduction in CAMEn, in turn, may be due to possible industrial inadequacies in the thermal processes following autoclaving (vapor at 105 to $120^{\circ} \mathrm{C}$ for 15 to $25 \mathrm{~min}$ ) as well as during the final drying of PBRB, which might have complexed proteins and increased the proportion of insoluble fibers in the feedstuff.

According to Rostagno et al. (2017), practical use levels of rice bran in broiler diets are 3 to $6 \%$ for the starter and grower phases, respectively. Gallinger et al. (2004) stated that, in the starter phase, up to $10 \%$ rice bran can be used with no losses to performance or bone mineralization in broilers. However, these inclusion values may be higher when more effective industrial processing is used to enhance the quality of PBRB. Zare-Sheibani et al. (2015) observed that the extrusion of brown rice allows for the inclusion of up to $30 \%$ of this ingredient in broiler diets, without affecting performance. Supriyati et al.
(2015) reported that previous fermentation of rice bran with Bacilllus amyloliquefaciens increased the protein fraction and gross energy, but reduced the crude fiber content, and so up to $15 \%$ could be included in broiler diets. Another factor that enables the inclusion of PBRB is the poultry category under study. Freitas et al. (2013) and Quevedo Filho et al. (2013) observed that 25 and 30\% inclusion, respectively, did not affect the performance of Japanese quail in the laying phase. Gopinger et al. (2015), in turn, concluded that brown rice bran can replace up to $80 \%$ of corn in the diet of Japanese quail, increasing egg production; however, it reduces yolk color due to the lack of carotenoids present in corn.

Sorghum protein meal is a combination, in undefined proportions, of protein by-products from the sorghum grain production chain, whose main ingredient is DDGS, derived from seasonal ethanol production when the price of sorghum grain is competitive with corn. Additionally, it contains protein biomass of yeasts used in the sorghum fermentation process for ethanol production and residues from germ and gluten production and sorghum oil extraction, but low starch contents. For this reason, in our study, a high CP content was observed in PSM. Despite the high protein content, there are limitations in the use of protein by-products of sorghum in diets for monogastrics.

For Liu et al. (2015), the main factors restricting the use of protein sorghum concentrates on a large scale are: tannin content in the grain, type of cultivar (the white variety having lower levels of phytate and non-tanning phenolic compounds and higher $\mathrm{CP}$ and AMEn values compared to red sorghum), grain processing (with variations in gelatinization or complexation of nutrients, mainly starch and proteins) and the concentration of kaffirin and glutelin, the main protein fractions in sorghum. Selle et al. (2017) stated that only kaffirin is related to increased protein in the endosperm of the sorghum grain, which may lead to low digestibility and complexation of carbohydrates and, mainly, amino 
acids. Applegate et al. (2009) declared that DDGS, the main ingredient of PSM, increases the dietary insoluble fiber. Fiber is known to have a nutrientdiluting effect, consequently increasing the rate of passage, reducing the retention time of the feed bolus and preventing satisfactory feed digestion. Those factors explain the low CAMEn in PSM found here $(57.35 \%)$.

There are no studies investigating the CP, AMEn, CAMEn, and insoluble fiber contents or practical recommendations of PSM inclusion in the diet of broilers. In the current study, PSM was found to contain $42.65 \% \mathrm{CP}$ and $2799 \mathrm{kcal}^{\mathrm{kg}}{ }^{-1}$ AMEn. These values are close to the $40.20 \% \mathrm{CP}$ and $2726 \mathrm{kcal} . \mathrm{kg}^{-1}$ AMEn observed by Rostagno et al. (2017) in semiwhole roasted soybean, which can be used at levels up to $30 \%$ in the diet of broilers in the grower and finisher phases. Mabelebe et al. (2018) observed that pelleting broiler diets containing whole sorghum $(10.90 \%$ CP) associated with supplementation with exogenous enzymes (xylanase and phytase) elevates feed intake, weight gain and the carcass yield in the phase of 1 to 35 days. This fact suggests the need for studies on PSM, especially involving its impact on performance, carcass characteristics and bioeconomic efficiency when partially replacing other high-cost protein ingredients such as soybean meal.

Bread waste meal showed the highest standardized ileal digestibility coefficients of $\mathrm{CP}$ and of essential and non-essential amino acids $(\mathrm{p}<0.01)$, followed by PBRB (Table 3). Despite its higher CP content, PSM showed the lowest standardized ileal digestibility coefficients of $\mathrm{CP}$ and of all amino acids (Table 3$)(\mathrm{p}<0.01)$.

Table 3. Means values of the standardized ileal digestibility coefficients of crude protein and amino acids of feedstuffs, expressed as a percentage in natural matter.

\begin{tabular}{lccccc}
\hline Feedstuffs & PBRB & SPM & BWM & CV (\%) & p-valor \\
\hline Crude protein & $57.04 \pm 4.71^{\mathrm{b}}$ & $37.53 \pm 3.94^{\mathrm{c}}$ & $90.53 \pm 1.22^{\mathrm{a}}$ & 5.86 & $<0.001$ \\
Essential amino acids & & & & & \\
Methionine & $65.79 \pm 5.73^{\mathrm{b}}$ & $44.44 \pm 5.68^{\mathrm{c}}$ & $91.88 \pm 1.51^{\mathrm{a}}$ & 7.03 & $<0.001$ \\
Lysine & $63.35 \pm 5.78^{\mathrm{b}}$ & $33.70 \pm 4.06^{\mathrm{c}}$ & $89.81 \pm 1.93^{\mathrm{a}}$ & 6.79 & $<0.001$ \\
Threonine & $51.57 \pm 8.37^{\mathrm{b}}$ & $31.34 \pm 6.14^{\mathrm{c}}$ & $95.29 \pm 1.70^{\mathrm{a}}$ & 10.22 & $<0.001$ \\
Tryptophan & $63.13 \pm .24^{\mathrm{a}}$ & $52.26 \pm 6.22^{\mathrm{a}}$ & - & & 0.065 \\
Valine & $59.97 \pm 5.15^{\mathrm{b}}$ & $36.12 \pm 4.49^{\mathrm{c}}$ & $89.63 \pm 1.62^{\mathrm{a}}$ & 6.54 & $<0.001$ \\
Leucine & $56.33 \pm 5.58^{\mathrm{b}}$ & $38.48 \pm 4.05^{\mathrm{c}}$ & $92.70 \pm 1.10^{\mathrm{a}}$ & 5.74 & $<0.001$ \\
Isoleucine & $57.14 \pm 5.13^{\mathrm{b}}$ & $35.70 \pm 3.98^{\mathrm{c}}$ & $90.09 \pm 1.57^{\mathrm{a}}$ & 6.32 & $<0.001$ \\
Arginine & $77.13 \pm 2.41^{\mathrm{b}}$ & $42.69 \pm 4.92^{\mathrm{c}}$ & $92.67 \pm 1.25^{\mathrm{a}}$ & 4.58 & $<0.001$ \\
Histidine & $73.47 \pm 4.81^{\mathrm{b}}$ & $39.63 \pm 5.23^{\mathrm{c}}$ & $91.96 \pm 0.87^{\mathrm{a}}$ & 6.04 & $<0.001$ \\
Phenylalanine & $56.55 \pm 4.39^{\mathrm{b}}$ & $41.60 \pm 4.48^{\mathrm{c}}$ & $93.93 \pm 0.88^{\mathrm{a}}$ & 5.71 & $<0.001$ \\
Non-essential amino acids & & & & \\
Glycine & $59.29 \pm 5.59^{\mathrm{b}}$ & $40.33 \pm 4.57^{\mathrm{c}}$ & $88.05 \pm 2.37^{\mathrm{a}}$ & 7.01 & $<0.001$ \\
Serine & $57.65 \pm 6.71^{\mathrm{b}}$ & $40.38 \pm 5.65^{\mathrm{c}}$ & $93.77 \pm 1.23^{\mathrm{a}}$ & 8.00 & $<0.001$ \\
Tyrosine & $60.91 \pm 8.23^{\mathrm{b}}$ & $27.53 \pm 3.82^{\mathrm{c}}$ & $92.94 \pm 0.83^{\mathrm{a}}$ & 8.70 & $<0.001$ \\
Alanine & $60.29 \pm 7.57^{\mathrm{b}}$ & $43.79 \pm 5.86^{\mathrm{c}}$ & $87.76 \pm 1.66^{\mathrm{a}}$ & 8.77 & $<0.001$ \\
Glutamic acid & $68.94 \pm 4.67^{\mathrm{b}}$ & $40.12 \pm 4.93^{\mathrm{c}}$ & $98.47 \pm 0.33^{\mathrm{a}}$ & 5.67 & $<0.001$ \\
Aspartic acid & $56.57 \pm 5.71^{\mathrm{b}}$ & $35.39 \pm 3.81^{\mathrm{c}}$ & $97.30 \pm 1.33^{\mathrm{a}}$ & 6.40 & $<0.001$ \\
Cystine & $53.06 \pm 14.16^{\mathrm{b}}$ & $37.10 \pm 7.34^{\mathrm{c}}$ & $96.41 \pm 1.99^{\mathrm{a}}$ & 14.92 & $<0.001$ \\
\hline
\end{tabular}

${ }^{\mathrm{a}-\mathrm{b}}$ Different letters in the same line differ by Tukey test $(\mathrm{p}<0.05)$. PBRB = Parboiled brown rice bran; PSM = Protein sorghum meal; BWM = Bread waste meal; CV $(\%)=$ Coefficient of variation; - = non detected. 
Among the standardized ileal digestibility coefficients of essential amino acids of BWM, the lowest $(89.63 \%)$ was found for valine and the highest $(95.29 \%)$ for threonine. The standardized ileal digestibility coefficients of non-essential amino acids, in turn, was lowest (87.76\%) for alanine and highest (98.47\%) for glutamic acid (Table 3).

Stefanello et al. (2016) observed that aging and increasing levels of bakery waste inclusion in the diet (up to 20\%) improves the utilization of $\mathrm{N}$ and of ileal digestible energy in broilers. This effect stems from increased jejunal expression of mucin, a sodium-dependent phosphate transporter and cationic amino acid transporter, consequently increasing the bioavailability of those amino acids.
Moreover, the other ingredients used in the making of breads, such as yeasts, stabilizing agents and preservatives may alter the processes of protein digestion and amino acid absorption by broilers. Those factors contributed to the high standardized ileal digestibility coefficients of amino acids in BWM, which averaged $92.72 \%$. This is an elevated value, if compared to the average $61.13 \%$ found for PBRB and $38.98 \%$ for PSM. The digestible amino acid contents of lysine, arginine, valine, isoleucine, leucine, histidine and phenylalanine from BWM were $0.40,0.62,0.78,0.53,1.05,0.27$ and $0.79 \%$, respectively (Table 4). These values were higher than the $0.20,0.47,0.47,0.39,0.77,0.23$ and $0.52 \%$ found by Rostagno et al. (2017) in BWM. However, the values for the other amino acids were close.

Table 4. Mean values of digestible amino acid values of feedstuffs, expressed as a percentage in natural matter.

\begin{tabular}{lccc}
\hline Feedstuffs & PBRB & PSM & BWM \\
\hline Essential amino acids & & & 0.24 \\
Methionine & 0.19 & 0.33 & 0.40 \\
Lysine & 0.40 & 0.46 & 0.45 \\
Threonine & 0.25 & 0.50 & - \\
Tryptophan & 0.13 & 0.28 & 0.78 \\
Valine & 0.44 & 0.73 & 1.05 \\
Leucine & 0.53 & 1.77 & 0.53 \\
Isoleucine & 0.25 & 0.59 & 0.62 \\
Arginine & 0.77 & 0.63 & 0.27 \\
Histidine & 0.26 & 0.35 & 0.79 \\
Phenylalanine & 0.30 & 0.79 & \\
Non-essential amino acids & & & 0.57 \\
Glycine & 0.44 & 0.56 & 0.77 \\
Serine & 0.38 & 0.85 & 0.49 \\
Tyrosine & 0.23 & 0.41 & 0.51 \\
Alanine & 0.53 & 1.47 & 5.25 \\
Glutamic acid & 1.15 & 2.70 & 0.61 \\
Aspartic acid & 0.66 & 1.06 & 0.21 \\
Cystine & 0.20 & 0.28 & \\
\hline
\end{tabular}

PBRB = Parboiled brown rice bran; PSM = Protein sorghum meal; $\mathbf{B W M}=$ Bread waste $\mathbf{m e a l} ;-=$ non detected .

Among the standardized ileal digestibility the lowest $(51.57 \%)$ was found for threonine and coefficients of essential amino acids in PBRB, the highest (77.13\%) for arginine. In the group of 
non-essential amino acids, the lowest (53.06\%) and highest (68.94\%) coefficients were found for cystine and glutamic acid, respectively (Table 3). The main limiting digestible amino acids in PBRB were found at the following values: methionine - $0.19 \%$, lysine - $0.40 \%$, threonine $-0.25 \%$ and valine - 0.44 (Table 4). No studies exist thus far addressing the standardized ileal digestibility coefficients and digestible amino acid contents of PBRB for broilers. Rostagno et al. (2017) observed that the concentrations of the main limiting amino acids in rice bran were $0.21 \%$ methionine, $0.47 \%$ lysine, $0.36 \%$ threonine and $0.54 \%$ valine. Thus, in our study, the parboiling process can be said to have reduced the methionine, lysine, threonine and valine levels by $5,10,28$ and $29 \%$, respectively. It should also be stressed that PBRB may be subject to variations inherent to plant-based feedstuffs such as cultivar, soil, planting system, location and industrial standardization in the management of raw grains, especially thermal processes.

The lowest standardized ileal digestibility coefficient of essential amino acids in PSM was $31.34 \%$, for threonine, and the highest was $52.26 \%$, for tryptophan. The lowest standardized ileal digestibility coefficient of non-essential amino acids was $27.53 \%$, for tyrosine, and the highest was $43.79 \%$, for alanine. However, because of its higher $\mathrm{CP}$ content in relation to the other feedstuffs under study, PSM also had the highest digestible amino acid contents, on average (Table 4). To the present date, no studies have been conducted on the standardized ileal digestibility of PSM in broiler diets.

According to Liu et al. (2015), ingredients that contain sorghum as the base of their composition have low levels of basic amino acids like lysine, arginine and histidine, mainly. This fact is further stressed when we compare PSM as a possible substitute for soybean meal, the main source of CP and digestible amino acids in broiler diets. Rostagno et al. (2017) reported that soybean meal (44\% CP) contains $2.54,3.11$ and $1.07 \%$ lysine, arginine and histidine, respectively. Those concentrations are higher than those found in the present study for PSM. This is also valid for the limiting amino acids methionine, threonine and valine, which are also higher in soybean meal than in PSM.

In general, the standardized ileal digestibility coefficients of the amino acids in PSM were low. This is due to the hydrophobicity of kaffirin, which constitutes up to $50 \%$ of the total protein in sorghum. As heat is supplied during the industrial processing of sorghum grain and its derivatives, the cross-links of disulfide bonds between the peripheral portions of kaffirin ( $\beta$ and $\gamma$ ) are strengthened, preventing the central portion of $\alpha$-kaffirin, which has the largest protein content, from being degraded (SELLE et al., 2013). In addition to the low digestibility of the protein fraction, the sorghum protein has greater affinity for forming starch-protein complexes, through non-phytate phenolic compounds (LIU et al., 2015), making it impossible to destroy the disulfide bonds of the protein complexes and leading to insolubility. This may occur even in cultivars lacking tannins and with low concentrations of phenolic compounds (SELLE et al., 2017).

Liu et al. (2013) observed that protease supplementation increased the ileal digestibility of protein and amino acids from sorghum-based broiler diets. Barekatain et al. (2013) also observed that protease and xylanase supplementation in broiler diets with 30\% inclusion of sorghum DDGS, the main ingredient originating PSM, increased the digestibility of dietary nutrients, favoring broiler performance. Moreover, Barekatain et al. (2014) detected an increase in the net energy content of the diet fed to broilers from 18 to 28 days of age after including 30\% sorghum DDGS and supplementing the diet with a blend of exogenous enzymes (protease, amylase, xylanase and glucanase). Therefore, as an alternative to overcome the low protein solubility of sorghum grain and its by-products, we recommend using exogenous enzymes in broiler diets with a view to increasing AMEn and protein digestibility, which are associated with increased amino acid availability (LIU et al., 2015). 


\section{Conclusion}

The AMEn and CAMEn values of PBRB, PSM and BWM for broilers were 2638, 2799 and 3399 kcal. $\mathrm{kg}^{-1}$ and 54.13, 57.35 and $86.66 \%$, respectively. BWM showed the highest AMEn and CAMEn values and standardized ileal digestibility coefficients of essential and non-essential amino acids among the three feedstuffs evaluated in this study. The main limiting digestible amino acids in PBRB, PSM and BWM were found at the following respective contents: methionine $-0.19,0.33$ and $0.24 \%$; lysine $-0.40,0.46$ and $0.40 \%$; threonine $0.25,0.50$ and $0.45 \%$; and valine $-0.44,0.73$ and $0.48 \%$.

\section{References}

APPLEGATE, T. J.; TROCHE, C.; JIANG, Z.; JOHNSON, T. The nutritional value of high-protein corn distillers dried grains for broiler chickens and its effect on nutrient excretion. Poultry Science, Champaign, v. 88, n. 2 , p. 354-359, 2009. DOI: $10.3382 /$ ps.2008-00346

ASSOCIATION OF OFFICIAL ANALYTICAL CHEMISTS - AOAC. Official methods of analysis of AOAC. $16^{\text {th }}$ ed. Washington: AOAC, 1995. 1094 p.

AYANRINDE, O. J.; OWOSIBO, A. O.; ADEYEMO, A. A. Performance characteristics of broilers fed bread waste based diets. International Journal of Modern Plant \& Animal Sciences, Florida, v. 2, n. 1, p. 1-11, 2014.

BAREKATAIN, M. R.; ANTIPATIS, C.; CHOCT, M.; IJI, P. A. Interaction between protease and xylanase in broiler chicken diets containing sorghum distillers' dried grains with solubles. Animal Feed Science and Technology, New York, v. 182, n. 1-4, p. 71-81, 2013. DOI: $10.1016 / \mathrm{j}$.anifeedsci.2013.04.002

BAREKATAIN, M. R.; NOBLET, J.; WU, S. B.; IJI, P. A.; CHOCT, M.; SWICK, R. A. Effect of sorghum distillers dried grains with solubles and microbial enzymes on metabolizable and net energy values of broiler diets. Poultry Science, Champaign, v. 93, n. 11, p. 1-9, 2014. DOI: $10.3382 /$ ps.2013-03766

BROCH, J.; OLIVEIRA, N. T. E.; NUNES, R. V.; HENZ, J. R.; SILVA, I. M.; FRANK, R.; SCHONE, R. A. Chemical composition and energetic values of wheat and its sub-products for broiler chicken. Semina: Ciencias Agrárias, Londrina, v. 36, n. 5, p. 3481-3488, 2015. DOI: $10.5433 / 1679-0359.2015 \mathrm{v} 36 \mathrm{n} 5 \mathrm{p} 3481$
DALÓLIO, F. S.; ALBINO, L. F. T.; ROSTAGNO, H. S.; SILVA, D. L.; XAVIER JÚNIOR, M. L.; OLIVEIRA, V. D. Avaliação nutricional e energética da soja integral tostada para frangos de corte. Arquivo Brasileiro de Medicina Veterinária e Zootecnia, Belo Horizonte, v. 69, n. 2, p. 437-444, 2017. DOI: 10.1590/1678-4162-9056

DENARDIN, C. C.; SILVA, L. P. Estrutura dos grânulos de amido e sua relação com propriedades físico-químicas. Ciência Rural, Santa Maria, v. 39, n. 3, p. 945-954, 2009. DOI: $10.1590 / \mathrm{S} 0103-84782009005000003$

DIAS, L. C. G. D.; REYES, F.; CAMARGO, J. L. V.; RODRIGUES, M. A. M. Conteúdo de celulose, hemicelulose e lignina no farelo de arroz fresco. Revista de Nutrição, Campinas, v. 7, n. 1, p. 62-70, 1994.

FREITAS, E. R.; QUEVEDO-FILHO, I. B.; WATANABE, P. H.; FILGUEIRA, T. M. B.; CRUZ, C. E. B.; TAVARES, T. C. L. Parboiled rice bran in Japanese quail diets growing phase and residual effect at laying period. Ciência e Agrotecnologia, Lavras, v. 37 , n. 4 , p. $350-358,2013$. DOI: $10.1590 / \mathrm{S} 1413-$ 70542013000400009

GALLINGER, C. I.; SUÁREZ, D. M.; IRAZUSTA, A. Effects of rice bran inclusion on performance and bone mineralization in broiler chicks. The Journal of Applied Poultry Research, Oxford, v. 13, n. 2, p. 183-190, 2004. DOI: $10.1093 / \mathrm{japr} / 13.2 .183$

GENEROSO, R. A. R.; GOMES, P. C.; ROSTAGNO, H. S.; ALBINO, L. F. T.; BARRETO, S. L. T.; BRUMANO, G. Composição química e energética de alguns alimentos para frangos de corte em duas idades. Revista Brasileira de Zootecnia, Viçosa, MG, v. 37, n. 7, p. 1251-1256, 2008. DOI: $10.1590 / \mathrm{S} 1516-35982008000700016$

GOPINGER, E.; MORAES, P. O.; CATALAN, A. A. S.; XAVIER, E. G.; CASTRO, M. L.; SCHAFHAUSER JÚNIOR, J. Whole rice in Japanese quails' diet. Acta Scientiarum. Animal Sciences, Maringá, v. 36, n. 4, p. 363367, 2015. DOI: 10.4025/actascianimsci.v36i4.24504

JOSLYN, M. A. Methods in food analysis: physical, chemical and instrumental methods of analysis. $2^{\text {th }}$ ed. New York: Academic Press, 1970. 845 p.

LACERDA, D. B. C. L.; SOARES JÚNIOR, M. S.; BASSINELO, P. Z.; CALIARI, M.; CASTRO, M. V. L. The kinetics of lipase activity and hydrolytic rancidity of raw, parboiled, and extruded rice bran during storage. Food Science and Techonology, Campinas, v. 33 , n. 2 , p. $376-381,2013$. DOI: 10.1590/S010120612013005000053

LIU, S. Y.; FOX, G.; KHODDAMI, A.; NEILSON, K. A.; TRUONG, H. H.; MOSS, A. F.; SELLE, P. H. Grain 
sorghum: a conundrum for chicken-meat production. Agriculture, Basel, v. 5, n. 4, p. 1224-1251, 2015. DOI: 10.3390/agriculture5041224

LIU, S. Y.; SELLE, P. H.; COURT, S. G.; COWIESON, A. J. Protease supplementation of sorghum-based broiler diets enhances amino acid digestibility coefficients in four small intestinal sites and accelerates their rates of digestion. Animal Feed Science and Technology, New York, v. 183, n. 3-4, p. 175-183, 2013. DOI: 10.1016/j. anifeedsci.2013.05.006

MABELEBE, M.; GOUS, R. M.; MASEY O’NEIL, H. V.; IJI, P. A. Whole sorghum inclusion and feed form on performance and nutrient digestibility of broiler chickens. Journal of Applied Animal Nutrition, Cambridge, v. 6, n. e5, p. 1-8, 2018. DOI: 10.1017/JAN.2018.3

NUNES, R. V.; ROSTAGNO, H. S.; ALBINO, L. F. T.; GOMES, P. C.; TOLEDO, R. S. Composição bromatológica, energia metabolizável e equações de predição da energia do grão e de subprodutos do trigo para pintos de corte. Revista Brasileira de Zootecnia, Viçosa, MG, v. 30, n. 3, p. 785-793, 2001. DOI: 10.1590/ S1516-35982001000300025

OKE, O. S. Utilization of bread waste meal as replacement for maize in diets for broilers chickens. Journal of Poverty, Investment and Development, London, v. 1, n. 1, p. 71-75, 2013.

QUEVEDO-FILHO, I. B.; FREITAS, E. R.; FIGUEIRA, T. M. B.; NASCIMENTO, G. A. J.; BRAZ, N. M.; FERNANDES, D. R.; WATANABE, P. H. Parboiled rice whole bran in laying diets for Japanese quails. Pesquisa Agropecuária Brasileira, Brasília, v. 48, n. 6, p. 582-588, 2013. DOI: $10.1590 /$ S0100-204X2013000600002

ROSTAGNO, H. S.; ALBINO, L. F. T.; DONZELE, J. L.; GOMES, P. C.; OLIVEIRA, R. F.; LOPES, D. C.; FERREIRA, A. S.; BARRETO, S. L. T.; EUCLIDES, R. F. Tabelas brasileiras para aves e suínos: composição de alimentos e exigências nutricionais. 3. ed. Viçosa, MG: UFV, 2011. 252 p.

ROSTAGNO, H. S.; ALBINO, L. F. T.; HANNAS, M. I.; DONZELE, J. L.; SAKOMURA, N. K.; PERAZZO, F. G.; SARAIVA, A.; ABREU, M. L. T.; RPDRIGUES, P. B.; OLIVEIRA, R. F.; BARRETO, S. L. T.; BRITO, C. O. Tabelas brasileiras para aves e suínos: composição de alimentos e exigências nutricionais. 4. ed. Viçosa, MG: UFV, 2017. 488 p.

SAKOMURA, N. K.; ROSTAGNO, H. S. Métodos de pesquisa em nutrição de monogástricos. 2. ed. Jaboticabal: FUNEP, 2016. 262 p.
SELlE, P. H.; LIU, S. Y.; CAI, J.; COWIESON, A. J. Steam-pelleting temperatures, grain variety, feed form and protease supplementation of mediumly ground, sorghum-based broiler diets: influences on growth performance, relative gizzard weights, nutrient utilization, starch and nitrogen digestibility. Animal Production Science, Victoria, v. 53, n. 5, p. 378-387, 2013. DOI: $10.1071 /$ AN12363

SEllE, P. H.; MOSS, A. F.; TRUONG, H. H.; KHODDAMI, A.; CADOGAN, D. J.; GODWIN, I. D.; LIU, S. Y. Outlook: Sorghum as a feed grain for Australian chicken-meat production. Animal Nutrition, Pequim, v. 4, n. 1, p. 17-30, 2017. DOI: 10.1016/j. aninu.2017.08.007

SHAHEEN, M.; AHMAD, I.; ANJUM, F. M.; SYED, Q. A.; SAEED, M. K. Effect of processed rice bran on growth performance of broiler chicks from Pakistan. Bulgarian Journal of Agricultural Science, Sófia, v. 21, n. 2, p. 440-445, 2015.

SILVA, D. J.; QUEIROZ, C. Análise de alimentos: métodos químicos e biológicos. 3. ed. Viçosa, MG: UFV, 2002. 235 p.

SILVA, E. A.; ALBINO, L. F. T.; ROSTAGNO, H. S.; RIBEIRO JUNIOR, V.; VIEIRA, R. A.; CAMPOS, A. M. A.; MESSIAS, R. K. G. Chemical composition and metabolizable energy values of feedstuffs for broiler chickens. Revista Brasileira de Zootecnia, Viçosa, MG, v. 41, n. 3, p. 648-654, 2012. DOI: 10.1590/S151635982012000300026

SISTEMA PARA ANÁLISES ESTATÍSTICAS E GENÉTICAS - SAEG. Versão 9.1. Viçosa, MG: Fundação Arthur Bernardes - UFV, 2007.

STEFANELLO, C.; VIEIRA, S. L.; XUE, P.; AJUWON, K. M.; ADEOLA, O. Age-related energy values of bakery meal for broiler chickens determined using the regression method. Poultry Science, Champaign, v. 95, n. 7, p. 1582-1590, 2016. DOI: 10.3382/ps/pew046

SUPRIYATI; HARYATI, T.; SUSANTI, T.; SUSANA, I. W. R. Nutritional value of rice bran fermented by Bacillus amyloliquefaciens and humic substances and its utilization as a feed ingredient for broiler chickens. Asian-Australian Journal of Animal Sciences, Seoul, v. 28, n. 2, p. 231-238, 2015. DOI: 10.5713/ajas.14.0039

ZARE-SHEIBAN, A. A.; ARAB, M.; ZAMIRI, M. J.; REZVANI, M. R.; DADPASAND, M.; AHMADI, F. Effects of extrusion of rice bran on performance and phosphorus bioavailability in broiler chickens. Journal of Animal Science and Technology, Seoul, v. 57, n. 26, p. 1-5, 2015. DOI: 10.1186/s40781-015-0059-z 
